\title{
Effect of Tillage Management Models and Seed Rates on Growth, Yield Attributes and Yield of Late Sown Varieties of Wheat in Rice Fallow
}

\author{
Hemant Kumar Gangwar ${ }^{1}$, Ghanshyam Singh ${ }^{1}$, Ashish Singh ${ }^{2 *}$, Pawan Jaiswal ${ }^{1}$, \\ Dinesh Kumar ${ }^{3}$, Sudhir Pal $^{3}$ and Mandvi Srivastava ${ }^{4}$
}
${ }^{1}$ Department of Agronomy, ${ }^{2}$ Department of Agricultural Meteorology, ${ }^{3}$ Department of Soil Science and Agricultural Chemistry, ANDUA\&T, Kumarganj, Ayodhya 224229, India ${ }^{4}$ Department of Genetics and Plant Breeding, SVPUA\&T Meerut, India

\author{
*Corresponding author
}

\section{A B S T R A C T}

\section{Keywords}

Wheat, Tillage management modules, Seed rates, Yield attributes and yield

\section{Article Info}

Accepted:

10 October 2019

Available Online:

10 November 2019
The field experiment was conducted at Agronomy Research Farm of Narendra Deva University of Agriculture and Technology Kumarganj, Faizabad (U.P.) during Rabi season of 2013-14 and 2014-15. Field experiment was conducted to study the effect of tillage management modules, seed rate and varieties on wheat with variety NW-1014 and HUW234 during Rabi season of 2013-14 and 2014-15. The treatment was replicated thrice in Split Plot Design. The experimental soil was silty loam in texture having $\mathrm{pH} 8.14$, OC\% 0.32 , EC $0.30 \mathrm{dSm}^{1,}$ available $\mathrm{N}: 160.40, \mathrm{P}: 12.68, \mathrm{~K}: 218.40 \mathrm{~kg} \mathrm{ha}^{1}$. The crop was sown on $30^{\text {th }}$ December and $6^{\text {th }}$ January and harvested on $3^{\text {rd }}$ and $8^{\text {th }}$ May of 2014-15 and 201516. Plant height increased by $6.21 \%$ and $3.17 \%$ in conventional tillage as compared to reduced tillage at harvest. The dry matter production was found in HUW-234 which was $8.80 \%$ and $8.36 \%$ higher as compared to the NW-1014 during the year 2013-14 and 201415. Highest grain yield was recorded with variety HUW-234 (27.08 and $\left.27.38 \mathrm{q} \mathrm{ha}^{-1}\right)$ as compared to NW-1014 (23.84 and $24.48 \mathrm{q} \mathrm{ha}^{-1}$ ), maximum straw yield was recorded with HUW-234 variety (31.06 and $33.01 \mathrm{q} \mathrm{ha}^{-1}$ ) which was significantly superior over NW1014 (30.00 and $31.12 \mathrm{q} \mathrm{ha}^{-1}$ ) variety and the maximum biological yield was recorded with HUW-234 which was significantly higher over NW-1014 variety in respective years. The tillage practices altered the grain yield. The maximum value of harvest index in conventional tillage and minimum in zero tillage during the year 2013-14 and 2014-15 respectively.

\section{Introduction}

Wheat (Triticum aestivum L.) is a crop of Poaceae family and one of the most leading cereals of many countries of the world including India. Wheat is cultivated worldwide over an area of about 222.16 million hectare with an annual production of about 752 million metric tonnes (Anonymous, 201617). In India during 2016 total food grains 
production was $205.43 \mathrm{mt}$, out of which, wheat production was $93.50 \mathrm{mt}$, in $30.93 \mathrm{~m}$ ha area with a productivity of 3.09 tones per ha (Anonymous, 2015-16). India is the second largest wheat producing country in the world, contributing about 34 percent of total food grain production. About $91 \%$ of the total wheat production is contributed by northern states.

Among them Uttar Pradesh ranks first with respect to area $(9.65 \mathrm{~m} \mathrm{ha})$ and production of (26.87 $\mathrm{mt}$ ) but the productivity $\left(2786 \mathrm{~kg} \mathrm{ha}^{-1}\right)$ is much lower as compared to Punjab (4596 $\mathrm{kg} \mathrm{ha}{ }^{-1}$ ) and Haryana $4407 \mathrm{~kg} \mathrm{ha}^{-1}$ (Anonymous, 2016). The major wheat producing countries are china, India, USA, France, Russia, Canada, Australia, Pakistan, Turkey, UK, Argentina, Iran and Italy. These countries contribute about $78.82 \%$ of the total wheat production. As far as India is concerned, about $90 \%$ of the total wheat production is contributed by northern states.

The late transplanting of rice or use of long duration varieties in low land delays the sowing of wheat from mid November to December. The preceding crops such as sugarcane, potato, toria etc. and other factors forced to sow the wheat as late as in the month of December and January leads to low production \& productivity.

Low temperature, poor mineral accumulation, less translocation of photosynthesis from source to sink, hot desiccating wind during milking stage forced premature drying, unsuitable location specific varieties, imbalanced nutrient management are responsible for yield under late sown wheat.

Wheat yield under late sown condition is poor due to the less exploitation of the potentialities of the crop and available resources. Reduction in yield is mainly caused by delayed emergence of seedlings and curtailing the growth and development period of the crop. Delayed emergence of crop followed by high temperature and hot desiccating winds during grain filling stage results forced maturity of late sown wheat because of dehydration which ultimately result in heavy reduction in the whole biomass and yield.

The HUW -234 variety was developed by BHU, Varanasi in 1986 with the parents HUW 12/SPRW. The variety was released by CVRC. This variety is suitable for late sown and irrigated conditions. NW 1014 is a wheat variety was release in 1998 by CVRC. The variety was developed by NDKVV, Faizabad.

The variety is widely adopted in the area NEPZ. Zero tillage farming (also called no-till or direct drilling) is a way of growing crops or pasture from year to year without disturbing the soil through tillage.

In agronomical research, the major emphasis should be laid in quantification of yield advantages of various tillage management modules over traditional tillage practices and how far the yield advantages can be explained in agronomical term reflecting in the improvement of plant population or in per plant yield or both. The per plant yield can further been explained in the term of number of grain and grain weight.

It is generally believed that tillage management may possibly improve the germination stand and vigour of the individual plant. To fully exploit the potential of high yielding varieties, the development of special non-monetary management practices like tillage practices is a prime need that promotes the efficient utilization of nutrients, water and space, reduces the cost of cultivation, save the seed and fertilizer, causes easiness in intercultural operations, better control of weeds, insect-pest and diseases. Keeping this idea in view, three tillage management 
modules are undertaken to find out the best tillage operation for late sown wheat intended for economical production.

\section{Materials and Methods}

The farm is located $42 \mathrm{~km}$ away from Faizabad city on Faizabad- Raebareily road at $26.47^{\circ} \mathrm{N}$ latitude and $82.12^{\circ} \mathrm{E}$ longitude and about 113 metres above the mean sea level. The treatment included various tillage management modules, seed rate and varieties viz. $\mathrm{M}_{1}$ : (Conventional tillage $), \mathrm{M}_{2}=$ reduced tillage and $\mathrm{M}_{3}=$ zero tillage main plot, $b$. Seed rate $\mathrm{kg} \mathrm{ha}^{-1}$ (sub-plot) viz. $\mathrm{S}_{1}=100 \mathrm{~kg} \mathrm{ha}^{-1}$, $\mathrm{S}_{2}=125, \mathrm{~S}_{3}=150$ and $\mathrm{c}$. Wheat varieties (subplot) $\mathrm{V}_{1}=\mathrm{NW}-1014$ and $\mathrm{V}_{2}=\mathrm{HUW}-234$. The treatment were replicated thrice in Split Plot Design. The experimental soil was silty loam in texture having $\mathrm{P}^{\mathrm{H}} 8.14$, OC\% 0.32, EC 0.30 $\mathrm{dSm}^{1}$, available $\mathrm{N}: 160.40, \mathrm{P}: 12.68, \mathrm{~K}: 218.40$ kg ha ${ }^{1}$.

The crop was sown om $30^{\text {th }}$ December and $6^{\text {th }}$ January and harvested on $3^{\text {rd }}$ and $8^{\text {th }}$ May of 2013-14 and 2014-15.Certified and pure seeds were tested for germination before sowing. Sowing was done on 30th December 2013 and 06 January 2015 using different seed rate 100,125 and $150 \mathrm{~kg} \mathrm{ha}^{-1}$. Sowing was done in rows $20 \mathrm{~cm}$ apart using zero tillage, reduced tillage and conventional tillage. Planking was also done in case of reduced tillage and conventional tillage.

In the gross plot a uniform dose of nitrogen @ $60 \mathrm{~kg} \mathrm{ha}^{-1}$ (half dose) through urea, phosphorus@60 kg ha ${ }^{-1}$ through single super phosphate and potassium @ $40 \mathrm{~kg} \mathrm{ha}^{-1}$ through murate of potash were applied to all treatments as basal dressing. Remaining half dose of nitrogen $\left(60 \mathrm{~kg} \mathrm{ha}^{-1}\right)$ through urea was top dressed in two equal doses. Wheat was harvested when the leaves and stems turn yellow and become finally dry. Two rows of border from both the side of the plot and $0.5 \mathrm{~m}$ length of both sides were harvested first and removed from the field and after that net plots were harvested separately.

Five plants were randomly selected from each plot. The plant height was measured in $\mathrm{cm}$. From the soil surface to basal portion of flag leaf at $30^{\text {th }}, 60^{\text {th }}, 90^{\text {th }}$ DAS and harvest stage of crop growth period. Five plants were randomly selected from border rows at 30, 60, 90 DAS and at harvest after sun drying, materials was kept in an oven at $65{ }^{\circ} \mathrm{C}$ till the constant weight. The average weight was recorded and presented as dry matter plant $^{-1}$ (g). Number of effective tillers (ear heads) were counted before harvesting from marked area of $\mathrm{m}^{-2}$ from three plants and average value was taken. Length of five selected spikes from each plot were measured carefully from the neck node to the tip of last grain and averaged out to get the length of single spike. Total number of spikelets from five selected spikes was counted and average values were recorded. One thousand grains from net plot were counted and weighed to get 1000 grains weight $(\mathrm{g})$.

All the above ground biomass of experimental crop of each plot was harvested, sun dried and weighed in $\mathrm{kg} \mathrm{plot}^{-1}$ to represent the biological yield and finally converted in to $\mathrm{qha}^{-1}$. The grains were obtained after thershing of the net plot area and the grain was weighted and expressed as gain yield $\mathrm{kg}_{\text {plot }}{ }^{-1}$ and finally converted into $\mathrm{q} \mathrm{ha}^{-1}$. The straw yield for each net plot was obtained by subtracting the grain yield from total biological yield and ultimately converted in to $\mathrm{q} \mathrm{ha}^{-1}$.

\section{Results and Discussion}

\section{Plant height}

The data on plant height recorded at 4 phenological growth stages i.e. 30, 60, 90 DAS and at harvest as influenced by different 
tillage management module, seed rate and varieties are presented in Table 1. No significant difference was noticed in plant height under tillage management module, seed rate and varieties at 30 DAS during both of the year. The plant height was observed significantly higher with Conventional tillage treatment over Reduced tillage but remained at par with Zero tillage at 60, 90 DAS and at harvest during both of the years. Plant height increased by $6.21 \%$ and $3.17 \%$ in conventional tillage as compared to reduced tillage at harvest during the year 2013-14 and 2014-15, respectively.

\section{Dry matter accumulation $\left(\mathrm{g} \mathrm{m}^{-2}\right)$}

Dry matter accumulation increased with the progression in crop age up to maturity. The rate of increase in dry matter accumulation was very slow in initial stage (up to 30 DAS) and it was found faster from 30 DAS to maturity of the crop during both the years of investigation. It is quite evident from the data given in Table 1 that the different tillage management modules and variety had no significant effect on dry matter accumulation but seed rate is significantly influenced at 30 DAS during both the years. Tillage management modules had significant effect on dry matter accumulation from 60 DAS to harvest stage of crop. Conventional tillage practices produce maximum dry matter accumulation at 60, 90 and at harvest. This was significantly higher over the zero tillage and reduced tillage during both the years. Dry matter production increased gradually from 30 DAS onwards but being determinate growth habit of the crop, the maximum dry matter production was recorded at harvest. Among the different seed rate, $150 \mathrm{~kg} \mathrm{ha}^{-1}$ recorded significantly higher dry matter production over $125 \mathrm{~kg} \mathrm{ha}^{-1}$ and $100 \mathrm{~kg} \mathrm{ha}^{-1}$ at 60,90 DAS and at harvest. At the time of harvest $7.41 \%$ and $7.18 \%$ dry matter increase was recorded in conventional tillage as compare to reduced tillage. Dry matter accumulation in wheat was also significantly affected by varieties at 60, 90 DAS and at harvest stages of crop growth. Variety HUW-234 recorded significantly higher dry matter accumulation at every stage of crop growth as compared to NW-1014. At harvest significant highest, dry matter production was found in HUW-234 which was $8.80 \%$ and $8.36 \%$ higher as compared to the NW-1014 during the year 2013-14 and 2014-15, respectively.

\section{Number of spikes $\mathbf{m}^{-2}$}

The data on number of spikes as influenced by various treatments have been presented in Table 2. It clearly indicates that the maximum number of spikes (190.11 and $192.72 \mathrm{~m}^{-2}$ ) was recorded with the application of conventional tillage significantly higher over zero tillage and reduced tillage treatments. The maximum number of spikes (188.72 and 190.83) was recorded with the application of $100 \mathrm{~kg} \mathrm{ha}^{-1}$ seed rate significantly influenced over 125 and $150 \mathrm{~kg} \mathrm{ha}^{-1}$ seed rate during both the year of investigation. It clearly indicates that the maximum number of spikes (193.52 and 196.00) was recorded under HUW-234 significant difference over NW-1014 during the year 2013-14 and 2014-15, respectively. The data of spike length as influenced by different tillage management module, seed rate and varieties presented in Table 2 showed that the tillage management module have varying significant effect on spike length of wheat. The largest spike length (9.12 and 9.14 $\mathrm{cm}$ ) was recorded with conventional tillage, which was significantly superior over the zero tillage and reduced. Similarly, spike length was significantly affected by seed rate. Largest spike length of wheat was recorded with $100 \mathrm{~kg} \mathrm{ha}^{-1}$ seed rate which was significantly higher over the $125 \mathrm{~kg} \mathrm{ha}^{-1}$ and $150 \mathrm{~kg} \mathrm{ha}^{-1}$ seed rate application. Spike length of wheat was also significantly affected by varieties of the wheat. The variety HUW-234 
recorded significantly large spike length $(9.26$ $\mathrm{cm}$ and $9.28 \mathrm{~cm}$ ) as compared to the NW-1014 $(8.60$ and $8.62 \mathrm{~cm}$ ) during the year 2013-14 and 2014-15, respectively.

\section{Spike length (cm)}

The data of spike length as influenced by different tillage management module, seed rate and varieties presented in Table 2 showed that the tillage management module have varying significant effect on spike length of wheat. The largest spike length (9.12 and 9.14 $\mathrm{cm})$ was recorded with conventional tillage, which was significantly superior over the zero tillage and reduced tillage during the year 2013-14 and 2014-15, respectively.

Similarly, spike length was significantly affected by seed rate. Largest spike length of wheat was recorded with $100 \mathrm{~kg} \mathrm{ha}^{-1}$ seed rate which was significantly higher over the 125 $\mathrm{kg} \mathrm{ha}^{-1}$ and $150 \mathrm{~kg} \mathrm{ha}^{-1}$ seed rate application. Spike length of wheat was also significantly affected by varieties of the wheat. The variety HUW-234 recorded significantly large spike length $(9.26 \mathrm{~cm}$ and $9.28 \mathrm{~cm})$ as compared to the NW-1014 $(8.60$ and $8.62 \mathrm{~cm})$ during the year 2013-14 and 2014-15, respectively.

\section{Number of spikelets spike ${ }^{-1}$}

The highest spikelets spike ${ }^{-1}$ (13.36 and 13.78) during the year 2013-14 and 2014-15, respectively) were recorded with conventional tillage, which was significantly larger over the zero tillage and reduced tillage. Similarly, seed rate affected the number of spikelets spike $^{-1}$ was significantly and highest spikelets per spike of wheat values were recorded with $150 \mathrm{~kg} \mathrm{ha}^{-1}$ (13.91 and 14.06) level which was significantly higher over the $100 \mathrm{~kg} \mathrm{ha}^{-1}$ and $125 \mathrm{~kg} \mathrm{ha}^{-1}$ application during the year 201314 and 2014-15 respectively. Number of spikelets spike $^{-1}$ was also found significantly affected by wheat cultivars and the cultivar
HUW-234 recorded significantly more spikelets per spike (13.52 and 14.41) as compared to the NW-1014 (11.96 and12.81) during the year 2013-14 and 2014-15, respectively.

\section{Grain yield (q ha $\left.{ }^{-1}\right)$}

The data pertaining to grain yield was recorded and presented in Table 3. The data revealed that the grain yield of wheat was also significantly affected by tillage management modules. The highest grain yield was recorded with conventional tillage (27.58 and $29.70 \mathrm{q}$ $\mathrm{ha}^{-1}$ ) which was significantly higher over reduced tillage and zero tillage. The grain yield increased by $11.61 \%$ and $12.75 \%$ in conventional tillage as compare to zero tillage during the year 2013-14 and 2014-15, respectively. The variation in wheat grain yield was observed significant due to seed rate. Grain yield of wheat 27.03 and $27.18 \mathrm{q}$ $\mathrm{ha}^{-1}$ was observed under $150 \mathrm{~kg} \mathrm{ha}^{-1}$ which was significantly higher over 100 and $125 \mathrm{~kg}$ $\mathrm{ha}^{-1}$ during the year 2013-14 and 2014-15, respectively. Among the varieties, maximum grain yield was recorded with variety HUW234 (27.08 and $27.38 \mathrm{q} \mathrm{ha}^{-1}$ ) as compared to NW-1014 (23.84 and 24.48 q ha ${ }^{-1}$ ) variety during the year 2013-14 and 2014-15, respectively.

\section{Straw yield $\left(\mathbf{q} \mathbf{h a}^{-1}\right)$}

Data pertaining to straw yield indicated that the tillage management module had significant effect on the straw yield of wheat Table 3 . Significantly higher straw yield (33.96 and $34.54 \mathrm{q} \mathrm{ha}^{-1}$ ) was recorded with conventional tillage than zero tillage and reduced tillage. The effect of seed rate in respect of straw yield of wheat was observed significant during both the years. The significantly higher straw yield was observed with $150 \mathrm{~kg}$ seed rate ( 33.46 and $33.78 \mathrm{q} \mathrm{ha}^{-1}$ ) over the treatment $100 \mathrm{~kg} \mathrm{ha}^{-1}$ and $125 \mathrm{~kg} \mathrm{ha}^{-1}$ seed rate during 
the year 2013-14 and 2014-15, respectively. Among the varieties, maximum straw yield was recorded with HUW-234 variety (31.06 and $33.01 \mathrm{q} \mathrm{ha}^{-1}$ ) which was significantly superior over NW-1014 (30.00 and $31.12 \mathrm{q}$ $\mathrm{ha}^{-1}$ ) variety, respectively during both the year of investigation.

\section{Biological yield (q ha $\left.{ }^{-1}\right)$}

Data pertaining to biological yield per hectare as influenced by different tillage management module, seed rate and varieties shown in Table 3 revealed that the tillage management module had significant effect and highest biological yield was recorded as 61.55 and $64.24 \mathrm{q} \mathrm{ha}^{-1}$ which was significantly higher over rest of the tillage management module during both the years. The effect of seed rate in respect of biological yield of wheat was observed significant in the year 2013-14 and 2014-15. The seed rate $150 \mathrm{~kg} \mathrm{ha}^{-1}$ recorded significantly higher biological yield as compared to the treatment where seed rate was @ 100 and $125 \mathrm{~kg} \mathrm{ha}^{-1}$ during both the years. Among the varieties, maximum biological yield was recorded with HUW-234 (58.14 and $60.39 \mathrm{q} \mathrm{ha}^{-1}$ ) which was significantly higher over NW-1014 variety (53.84 and $55.60 \mathrm{q} \mathrm{ha}^{-}$ ${ }^{1}$ ) in respective years.

\section{Harvest index}

The data on harvest index as influenced by tillage management module, seed rate and varieties are presented in Table 3. Highest harvest index (44.80 and $46.23 \%)$ was recorded under conventional tillage and lowest harvest index was observed in zero tillage (43.65 and $43.80 \%$ ) during both the years, respectively. The effect of seed rate in respect of harvest index was also observed nonsignificant. The treatment having $100 \mathrm{~kg} \mathrm{ha}^{-1}$ seed rate application, recorded the highest harvest index (44.39 and 45.02\%) but lowest harvest index (43.59 and $44.51 \%)$ was observed with $150 \mathrm{~kg} \mathrm{ha}^{-1}$ seed rate during the year 2013-14 and 2014-15, respectively. Among the varieties, higher harvest index was recorded with HUW-234 in comparison to NW-1014 in both of the years but the varietal effect was non-significant on the harvest index during both the years.

Tillage practices significantly affected the plant height with the age of crop (Table 1). Initially, the difference in plant height was non-significant at $30^{\text {th }}$ day stage of the crop which was due to less time available for growth and development of plant. The increased plant height with conventional tillage followed by zero tillage and reduced tillage at later stages might be due to the cumulative effect of seedling method which resulted into good plant establishment and good pulverization with this tillage practice and thus by the effect of these factors, increased plant height was recorded. The similar finding has also been reported Pravesh, R. (2007). Tillage practices brought significant differences in dry matter accumulation at all the stages, except $30^{\text {th }}$ day stage of crop growth. The higher dry matter accumulation was recorded with conventional tillage followed by zero tillage and reduced tillage, respectively. The higher dry matter was associated with conventional tillage and sowing on zero tillage mainly due to good soil environment which resulted in higher growth and development. Similar findings were also observed by Khanali et al., (2012) and Pravash Ram (2007).

The yield attributing characters, number of spike $\mathrm{m}^{-2}$, spike length and number of spikelets spike $^{-1}$ enhanced significantly but 1000 grain weight was not significantly affected with each increase in seed rate during both the year. Significant improvement in yield attribute due to increase in 100 to $150 \mathrm{~kg}$ $\mathrm{ha}^{-1}$ seed rate have also been recorded by Singh and Prasad (1998). 
Table.1 Effect of tillage management models and seed rates on growth of late sown rice

\begin{tabular}{|c|c|c|c|c|c|c|c|c|c|c|c|c|c|c|c|c|}
\hline \multirow[t]{3}{*}{ Treatment } & \multicolumn{8}{|c|}{ Plant height $(\mathrm{cm})$} & \multicolumn{8}{|c|}{ Dry matter accumulation $\left(\mathrm{g} \mathrm{m}^{-2}\right)$} \\
\hline & \multicolumn{2}{|c|}{30 DAS } & \multicolumn{2}{|c|}{60 DAS } & \multicolumn{2}{|c|}{90 DAS } & \multicolumn{2}{|c|}{ At harvest } & \multicolumn{2}{|c|}{30 DAS } & \multicolumn{2}{|c|}{60 DAS } & \multicolumn{2}{|c|}{90 DAS } & \multicolumn{2}{|c|}{ At harvest } \\
\hline & $\begin{array}{c}2013- \\
14\end{array}$ & $\begin{array}{c}2014- \\
15\end{array}$ & $\begin{array}{c}2013- \\
14\end{array}$ & $\begin{array}{c}2014- \\
15\end{array}$ & $\begin{array}{c}2013- \\
14\end{array}$ & $\begin{array}{c}2014- \\
15\end{array}$ & $\begin{array}{c}2013- \\
14\end{array}$ & \begin{tabular}{|c}
$2014-$ \\
15
\end{tabular} & $\begin{array}{c}2013- \\
14\end{array}$ & $\begin{array}{c}2014- \\
15\end{array}$ & $\begin{array}{c}2013- \\
14\end{array}$ & $\begin{array}{c}2014- \\
15\end{array}$ & $\begin{array}{c}2013- \\
14\end{array}$ & $\begin{array}{c}2014- \\
15\end{array}$ & $\begin{array}{c}2013- \\
14\end{array}$ & $\begin{array}{c}2014- \\
15\end{array}$ \\
\hline \multicolumn{17}{|c|}{ Main plot (tillage management module) } \\
\hline Conventional & 18.17 & 19.67 & 55.67 & 59.50 & 83.67 & 87.43 & 86.56 & 88.50 & 76.18 & 79.27 & 432.11 & 438.86 & 606.96 & 620.60 & 811.01 & 820.38 \\
\hline Reduced & 17.06 & 18.39 & 52.72 & 57.02 & 78.61 & 83.12 & 81.50 & 85.78 & 71.66 & 73.99 & 383.88 & 393.02 & 555.62 & 570.28 & 755.04 & 765.36 \\
\hline Zero & 17.61 & 19.50 & 55.06 & 58.00 & 80.67 & 86.67 & 84.78 & 86.84 & 74.60 & 76.46 & 403.90 & 414.85 & 579.37 & 596.01 & 787.78 & 798.59 \\
\hline SEm \pm & 0.37 & 0.41 & 0.65 & 0.63 & 1.15 & 0.55 & 0.67 & 0.52 & 1.55 & 1.78 & 0.93 & 0.79 & 0.99 & 0.50 & 1.45 & 0.96 \\
\hline CD at $5 \%$ & NS & $\mathrm{NS}$ & 2.26 & 2.46 & 4.53 & 2.14 & 2.64 & 2.03 & NS & NS & 3.64 & 3.10 & 3.88 & 1.96 & 5.70 & 3.79 \\
\hline \multicolumn{17}{|c|}{ Sub plot (seed rate $\mathrm{kg} \mathrm{ha}^{-1}$ ) } \\
\hline 100 & 17.44 & 19.06 & 53.89 & 57.17 & 79.56 & 85.78 & 82.17 & 85.89 & 72.95 & 73.59 & 399.55 & 407.55 & 573.82 & 586.71 & 775.16 & 783.02 \\
\hline 125 & 17.00 & 18.78 & 55.00 & 58.22 & 81.00 & 85.56 & 84.44 & 86.44 & 74.07 & 75.16 & 406.52 & 415.77 & 580.06 & 595.18 & 784.97 & 794.44 \\
\hline 150 & 18.39 & 19.72 & 56.56 & 59.78 & 82.39 & 87.89 & 85.22 & 88.28 & 75.42 & 76.97 & 413.81 & 423.42 & 588.08 & 605.00 & 793.70 & 806.87 \\
\hline SEm \pm & 0.54 & 0.39 & 0.74 & 0.73 & 0.67 & 1.20 & 0.59 & 0.94 & 0.36 & 0.33 & 0.86 & 0.60 & 1.63 & 0.61 & 1.78 & 0.85 \\
\hline CD at $5 \%$ & NS & NS & 2.13 & 2.10 & 1.92 & 3.47 & 1.71 & 2.71 & 1.03 & 0.97 & 2.49 & 1.72 & 4.70 & 1.76 & 5.13 & 2.46 \\
\hline \multicolumn{17}{|c|}{ Sub plot (Variety) } \\
\hline NW-1014 & 17.20 & 18.89 & 54.20 & 57.07 & 78.70 & 83.04 & 80.52 & 83.07 & 80.44 & 63.52 & 382.77 & 390.58 & 551.96 & 566.82 & 751.53 & 762.90 \\
\hline HUW-234 & 18.02 & 19.48 & 56.09 & 59.70 & 83.26 & 89.78 & 87.37 & 90.67 & 83.85 & 86.96 & 430.49 & 440.57 & 609.34 & 624.43 & 817.69 & 826.66 \\
\hline SEm \pm & 0.31 & 0.36 & 0.60 & 0.60 & 0.54 & 0.98 & 0.48 & 0.77 & 1.29 & 1.27 & 0.70 & 0.49 & 1.33 & 0.50 & 1.45 & 0.70 \\
\hline CD at $5 \%$ & NS & $\mathrm{NS}$ & 1.74 & 1.72 & 1.57 & 2.84 & 1.39 & 2.21 & NS & NS & 2.03 & 1.40 & 3.84 & 1.44 & 4.20 & 2.01 \\
\hline
\end{tabular}


Table.2 Effect of different treatments on number of spikes $\mathrm{m}^{-2}$, spike length $(\mathrm{cm})$, number of spikelets spike ${ }^{-1}$ of wheat under late sown conditions

\begin{tabular}{|c|c|c|c|c|c|c|c|c|}
\hline \multirow[t]{2}{*}{ Treatment } & \multicolumn{2}{|c|}{ Number of spikes $\mathbf{m}^{-2}$} & \multicolumn{2}{|c|}{ Spike Length (cm) } & \multicolumn{2}{|c|}{ Number of spikelets spike ${ }^{-1}$} & \multicolumn{2}{|c|}{ 1000- grain weight (g) } \\
\hline & 2013-14 & 2014-15 & 2013-14 & 2014-15 & 2013-14 & 2014-15 & 2013-14 & 2014-15 \\
\hline Conventional & 190.11 & 192.72 & 9.12 & 9.14 & 13.36 & 13.78 & 33.58 & 33.71 \\
\hline Zero & 187.78 & 190.00 & 8.89 & 8.92 & 12.77 & 13.22 & 33.12 & 33.82 \\
\hline SEm \pm & 0.10 & 0.14 & 0.002 & 0.003 & 0.21 & 0.18 & 0.27 & 0.34 \\
\hline CD at $5 \%$ & 0.40 & 0.55 & 0.007 & 0.011 & 0.64 & 0.55 & NS & NS \\
\hline 125 & 187.56 & 190.06 & 8.93 & 8.95 & 12.19 & 13.61 & 33.26 & 33.52 \\
\hline 150 & 188.72 & 190.83 & 8.92 & 8.94 & 13.91 & 14.06 & 33.29 & 33.66 \\
\hline SEm \pm & 0.21 & 0.18 & 0.003 & 0.002 & 0.57 & 0.18 & 0.21 & 0.33 \\
\hline CD at $5 \%$ & 0.59 & 0.52 & 0.007 & 0.006 & 1.72 & 0.50 & NS & NS \\
\hline \multicolumn{9}{|c|}{ Sub plot (Variety) } \\
\hline NW-1014 & 181.63 & 183.96 & 8.60 & 8.62 & 11.96 & 12.81 & 33.93 & 34.26 \\
\hline
\end{tabular}


Table.3 Effect of different treatments on yields and harvest index (\%) of wheat under late sown conditions

\begin{tabular}{|c|c|c|c|c|c|c|c|c|}
\hline \multirow[t]{2}{*}{ Treatment } & \multicolumn{2}{|c|}{$\begin{array}{l}\text { Grain yield } \\
\quad\left(\mathbf{q} \mathbf{h a}^{-1}\right)\end{array}$} & \multicolumn{2}{|c|}{$\begin{array}{l}\text { Straw yield } \\
\quad\left(\mathbf{q} \mathbf{h a}^{-1}\right)\end{array}$} & \multicolumn{2}{|c|}{$\begin{array}{l}\text { Biological yield } \\
\left.(\mathbf{q ~ h a})^{-1}\right)\end{array}$} & \multicolumn{2}{|c|}{ Harvest index (\%) } \\
\hline & 2013-14 & 2014-15 & 2013-14 & 2014-15 & 2013-14 & 2014-15 & 2013-14 & 2014-15 \\
\hline \multicolumn{9}{|c|}{ Main plot (tillage management module) } \\
\hline Conventional & 27.58 & 29.70 & 33.96 & 34.54 & 61.55 & 64.24 & 44.80 & 46.23 \\
\hline Reduced & 20.37 & 21.83 & 25.85 & 27.73 & 46.22 & 49.56 & 44.12 & 44.07 \\
\hline Zero & 24.71 & 26.34 & 31.79 & 33.75 & 56.58 & 60.09 & 43.65 & 43.80 \\
\hline SEm \pm & 0.08 & 0.09 & 0.06 & 0.16 & 0.11 & 0.18 & 0.08 & 0.12 \\
\hline CD at $5 \%$ & 0.32 & 0.34 & 0.25 & 0.64 & 0.42 & 0.69 & 0.32 & 0.38 \\
\hline \multicolumn{9}{|c|}{ Sub plot (seed rate $\mathrm{kg} \mathrm{ha}^{-1}$ ) } \\
\hline 100 & 24.65 & 24.95 & 27.55 & 30.46 & 51.81 & 55.11 & 44.39 & 45.02 \\
\hline 125 & 25.90 & 26.05 & 30.59 & 31.77 & 54.64 & 57.82 & 43.67 & 44.94 \\
\hline 150 & 27.03 & 27.18 & 33.46 & 33.78 & 56.91 & 60.95 & 43.59 & 44.51 \\
\hline SEm \pm & 0.14 & 0.20 & 0.09 & 0.21 & 0.15 & 0.34 & 0.17 & 0.12 \\
\hline CD at $5 \%$ & 0.40 & 0.58 & 0.26 & 0.61 & 0.44 & 0.97 & 0.48 & 0.38 \\
\hline \multicolumn{9}{|c|}{ Sub plot (Variety) } \\
\hline NW-1014 & 23.84 & 24.48 & 30.00 & 31.12 & 53.84 & 55.60 & 44.27 & 44.02 \\
\hline HUW-234 & 27.08 & 27.38 & 31.06 & 33.01 & 58.14 & 60.39 & 46.57 & 45.33 \\
\hline SEm \pm & 0.11 & 0.17 & 0.07 & 0.17 & 0.12 & 0.27 & 0.14 & 0.18 \\
\hline CD at $5 \%$ & 0.33 & 0.48 & 0.21 & 0.50 & 0.36 & 0.79 & 0.40 & 0.51 \\
\hline
\end{tabular}

The tillage practices affected the grain yield. The higher Grain yield was recorded with conventional tillage followed by zero tillage.

This might be due to surface pulverization of soil comparatively for longer period with conventional tillage, which recorded higher yield attributes resulting in maximum grain yield. Similar research findings were also reported by Khan Ali et al., (2012), Kadian et al., (2005), and Panday et al., (2001).

The tillage practices affected the straw yield. The higher straw yield was recorded with conventional tillage followed by zero tillage and reduced tillage. This might be due to surface pulverization of soil comparatively as discussed in case of grain yield under conventional tillage, which recorded higher yield attributes resulting in maximum straw yield. Similar research findings were also reported by Roy et al., (1993) and Tripathi and
Chauhan (2001). Tillage practices affected the biological yield.

The higher biological yield was recorded with conventional tillage followed by zero tillage and reduced tillage. This might be due to surface pulverization of soil comparatively for longer period which recorded better yield attributes.

Sen et al., (2002) and Halvorson et al., (2000) also reported similar findings. Yield is the result of coordinated inter play of growth characters and yield attributes. Grain and straw yield significantly influenced by different tillage practices. Higher grain yield was recorded under conventional tillage. The tillage practices altered the grain yield. The maximum value of harvest index (44.80 and 46.23 ) in conventional tillage and minimum in zero tillage. Similar result had also been reported by Singh et al., (2003). On the basis 
of results, it may be recommended treatment for farmer $\mathrm{M}_{1} \mathrm{~S}_{3} \mathrm{~V}_{2}$ (conventional tillage, 150 $\mathrm{kg}$ seed rate $\mathrm{ha}^{-1}$ and HUW-234 for growing of late sown wheat in eastern part of Uttar Pradesh.

\section{References}

Anonymous (2015-16). Progress report of All India Co-ordinated Wheat \& Barley Improvement Project 2012-2013, Project Directors Report. Directorate of Wheat Research, Karnal, India, P-01.

Anonymous (2016). Economic survey of India. Economics Division, Ministry of Finance, Govt. of India.

Khanali, M., Komleh, P. H. S., Movahhedi, M.and Rafiee, S. (2012). Effects of tillage system and seed rate on dryland wheat production in the central region of Iran. Elixir Agriculture, 52:11326-11330.

Kadian, V. S., Yadav, A., Malik, R. S. and Malik, R. K. (2005). Long-term Double Zero-tillage in Sorghum (fodder)-Wheat in South-western Haryana. Acceleration of Resource Conservation Technology-Workshop Proceedings

Panday, I. B., Sharma S. L., Tiwari, S. S. and Bharti, V. (2001). Effect of tillage and weed management on grain yield and nutrients removal by wheat (Triticum aestivum L.) Indian Journal of weed science, 33 (3,4): 174-176.

Tripathi, S. C. and Chauhan, D. S. (2001). Effect of tillage and fertilizer on productivity of wheat (Triticum aestivum L.) under dry seeded and transplanted rice conditions. Indian Journal of Agronomy, 46(1): 17-111.

Roy, I., Sarker, A. K. D. and Razzaque, M. A. (1993). Wheat response to different tillage methods under irrigated and rainfed conditions of Bangladesh. Philipp J. Crop Sci., 18(1): 4549.
Sen, A., Pandey, M.D., Sharma, S.N. R., Kumar, A., Shukla, P. and Srivastava, V. K. (2003). Surface seeding of wheat (Triticum aestivum L.) as affected by seed rate and nitrogen level. Indian J. of Agricultural Sci., 73(9): 509-511.

Singh, Avtar; Mahey, R. K., Brar, S. S., Virk, A. S. and Singh, J. (2002). Effect of first, subsequent irrigation (s) and tillage on grain yield, nutrients uptake, rooting density of wheat, soil moisture content, consumptive use and water use efficiency. Res. on Crops,3 (1): 1-10.

Sarika, T. P., Sharma, A., Medhi, B. K. and Sharma, A. (2000). Performance of new wheat varieties for late sown condition in western Orissa. Environment of Ecology, 9 (4): 544-545.

Ram, A., Pannu, R. K. and Prasad, D. (2012). Effect of management practices on growth, yield and quality of late sown wheat (Triticum aestivum L.) Indian J. of Agron., 57(1): 92-95.

Agrawal, R. P., Phogat, V. K., Chand, T. and Grewal, M. S. (1995).Improvement of soil physical conditions in Haryana (Research highlights, 1967-1994).HAU, Hisar Publication, pp-66.

Pravash, R. (2007). Response of wheat to phosphorus levels and weed control under different tillage in rice wheat cropping system. Ph.D. Thesis submitted to N.D.U.A\&T. Kumarganj Faizabad (U.P.) India.

Sharma, J. C. and Acharya, C. L. (1997). Response of wheat (Triticum aestivum L.) grown on an acidic alfisol to nitrogen and tillage. Indian Journal of Agronomy, 42(4): 622-625.

Legere, A. and Bai, Y. (1999). Competitive attributes of $O$. sativa, T. aestivum and $H$. vulgare under no till cropping systems. Weed Science,47:712719.

Singh, G., Kumar D. and Verma S. K. (2006). Effect of tillage and nitrogen levels on productivity of wheat after rice. National Symp. On Conser. Agril. and Environ, Oct-26-28 BHU, Varanasi pp-21-22.

\section{How to cite this article:}

Hemant Kumar Gangwar, Ghanshyam Singh, Ashish Singh, Pawan Jaiswal, Dinesh Kumar, Sudhir Pal and Mandvi Srivastava. 2019. Effect of Tillage Management Models and Seed Rates on Growth, Yield Attributes and Yield of Late Sown Varieties of Wheat in Rice Fallow. Int.J.Curr.Microbiol.App.Sci. 8(11): 1035-1044. doi: https://doi.org/10.20546/ijcmas.2019.811.122 